\title{
Surfaces
}

\section{The Intellectual as a Contemporary Phenomenon}

\section{Paul A. Bové}

Volume 2, 1992

ACTES DU COLLOQUE « REPENSER LA CULTURE » ACTS OF THE CONFERENCE "RETHINKING CULTURE"

URI : https://id.erudit.org/iderudit/1065222ar

DOI : https://doi.org/10.7202/1065222ar

Aller au sommaire du numéro

\section{Éditeur(s)}

Les Presses de l’Université de Montréal

ISSN

1188-2492 (imprimé)

1200-5320 (numérique)

Découvrir la revue

Citer ce document

Bové, P. A. (1992). The Intellectual as a Contemporary Phenomenon. Surfaces, 2. https://doi.org/10.7202/1065222ar

\section{Résumé de l'article}

Bové élabore une vision libératrice plutôt que simplement historiciste de l'actualité de l'intellectuel, à travers une lecture de Spinoza et de Negri.
Copyright (C) Paul A. Bové, 1992

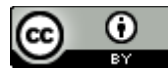

Ce document est protégé par la loi sur le droit d'auteur. L’utilisation des services d’Érudit (y compris la reproduction) est assujettie à sa politique d'utilisation que vous pouvez consulter en ligne.

https://apropos.erudit.org/fr/usagers/politique-dutilisation/ 
CONFERENCE PROCEEDINGS

"RETHINKING CULTURE"

The Intellectual as a Contemporary Phenomenon

Paul Bové

Cette conférence a été donnée au colloque

Repenser la culture

qui s'est tenu à l'Université de Montréal, les 3, 4 et 5 avril 1992.

Les organisateurs tiennent à remercier, pour leur soutien financier:

le Conseil de Recherche en Sciences Humaines du Canada

la Faculté des Arts et des Sciences, Université de Montréal

le Vice-rectorat à l'enseignement et à la recherche, Université de Montréal

le Département de Littérature comparée, Université de Montréal

Alitalia

ABSTRACT 
A reading of Spinoza and Negri in order to rethink the terms of intellectual contemporaneity in liberatory rather than merely historical terms.

\section{RÉSUMÉ}

Bové élabore une vision libératrice plutôt que simplement historiciste de l'actualité de l'intellectuel, à travers une lecture de Spinoza et de Negri.

"Contemporary," contemporain, always means the same and always the same as and within the now. From the Larousse: "Qui est du même temps"; "Qui est du temps présent." - From Webster's: "living or happening in the same period of time .... of about the same age ... . living or happening at the same time as." All of this depends upon time imagined as sequence, as calendar, as homogeneously extensive. In the conceptual space of this sense, intellectuals are not contemporary.

With what could they be the same? With whom?

Part of the problem, of course, is that "intellectuals" cannot be spoken of as such, tout court. But we know this and we speak as if we understand what we know when we talk about "specificity," about "positionality," and other such notions meant not only to recognize the nonidentity of intellectuals as a group in and between societies and cultures, but also to assert the political virtues of certain intellectual groups and practices over and against others.

There is a long tradition of such reflection: in one sense it is all postNietzschean since it rests on something else we like to call "perspectivism."[1] It has a small story to it: we are all situated somewhere when we write on the situated intellectuals who are either our subjects or who, in imagination, represent our ideals. Therefore, so the story goes, we are all historical in our thinking and political in our understanding of the affiliation of intellectuals to groups and cultures. Intellectuals then are also political, always and everywhere, and it is our task to explain in what ways, in which positions, to which ends, and in whose interests.[2] The story can be elaborated through accretion: new dimensions can be added from reality, 
e.g., gender and race; new dimensions can be added as concepts, e.g., hegemony and power.

But how can we do all this? Is there some unique subjectivity which makes it everywhere possible at the same time? If so, whence that subjectivity? But isn't it a particularity of intellectuals to reflect on subjectivity, etc.? (Of course, we can all provide answers based on stories of conditioning.)

Hegel tells us in the "Preface" to The Phenomenology that in most intellectuals' thought does not move (this can be dogmatism or science); it reifies into regularities of repetition that fail the spirit itself. There can be no better instance of such intellectual self-reflection than Hegel's foundational act -- which itself comes not long after the famous act of Kant reflecting on the contemporary in his essay on Aufklärung (1784), a reflection which announces the historical necessity of modern intellectuals' preoccupation with the contemporary.[3]

Hegel, we might suppose, is like Spinoza in desiring that the intellectual instantiate the new and drive the future with a compulsive will. But that would be wrong. Negri's Savage Anomaly catches Spinoza in the act of writing the philosophy of the market.[4] Spinoza, we might say, comes too early in the history of the market to desire that intellectuals drive spirit: perhaps, as Negri suggests, Spinoza can sense the opportunity that the market (and colonial exploration) offer to think anew of production, to think of human freedom and liberation, to imagine metaphysics as political. Hegel, by contrast, thinks only of and towards the state.

Foucault is like that Spinoza in detesting the intellectual will's drive toward absolutism; Foucault is often anarchic. [5] So early and late in one story of capital the intellectual is not contemporary: Spinoza goes where the market will not; this makes him Negri's philosopher of the future: he is in a different time. Foucault surpasses "exploitation" to understand "domination" when it becomes necessary to map how the contemporary would have it that we should understand subjectivity as formed by the operations of culture. Spinoza and Foucault write general theories of materialism: but theirs is not contemporary work because it moves as the future, as "power," a term in Spinoza as well as Foucault, moves to remake reality. 
Foucault, I would say in an act of some self-revision, is not the poststructuralist philosopher who makes "culture" available for critical analysis through a study of such realities as "discourse" and "power." Foucault rather is a thinker of past ways culture worked in relation to certain clearly known forms of economy and politics. [6] Foucault, we recall, insists that we know who exploits whom; we don't know who gets dominated or how domination works. Another way to put this is to say that we all come after Marx as we all also come after the spinning wheel, the prison, the state, and national political economies. We all also come after the cinema and most media, but we may not come after the new global structures of finance and production, after new modes of circulation that produce new realities around us and new subjectivities which are, to speak spiritually, "within us." (In part, it is impossible to tell where we "are" since movement in the turbulence within which order and intelligence might inhere is to rapid and disorienting to allow the stability of self-knowledge.) This makes Foucault that peculiar creature, the belated philosopher of the future. And it makes him the materialist par excellence: Foucault, in a now infamous moment in Discipline and Punish, tells us how micro-practices form the human soul; a claim more materialist perhaps than anything to be found in Marx -- who had a nostalgia for Greek tragedy -- or even in Spinoza who had recourse to a materialist theory of imagination to explain something like the incarnation of soul in being.

\section{III}

In The Metaphysics, Aristotle tells us that philosophy "is not a productive science" (317). He instructs us that ignorance motivates philosophical thinking:

It is through wonder that men now begin and originally began to philosophize; wondering in the first at obvious perplexities, and then by gradual progression raising questions about the greater matters too .... Now he who wonders and is perplexed feels that he is ignorant . . . therefore if it was to escape ignorance that men studied philosophy, it is obvious that they pursued science for the sake of knowledge and not for any practical utility.

We remember that this science is "independent," and so it seems God alone can have it; but, Aristotle insists, it is not beyond human power to acquire this knowledge, but its acquisition requires that we study the science of substance. 
Spinoza and Marx find materialism in Aristotle; it is a materialist effort to raise questions about greater matters based on the obvious perplexities that confront our senses and trouble our understanding. Marx revises this by insisting that we must try to change the world; from this flows politics and it, in turn, flows from the Hegelian insistence on will moving the real toward the absolute. Negri believes that Spinoza had a sense of freedom as collective within the market and that "bourgeois ideology," called variously Spinozism, Hobbesianism, or liberalism, proposed contracts and individuals as the substitute for collective freedom and the power to produce reality: freedom is the power to be collective and, as such, to constitute reality as freedom. But Negri is equally sure that Spinoza is always suspicious of the will figured either as individual or collective. The collective is not an organic whole engaged in a process of self-formation, as one reading would suggest Gramsci took it to be; it is, rather, a mechanism.[7] For Spinoza, the subject is always a "composite individual." How it is determined or affected is an important issue in The Ethics, and considering it moves Spinoza, as Negri indicates, from the microcosm to the macrocosm. Here is Spinoza from the "Second Part of the Ethics: On the Nature and Origin of the Mind." Proposition 13 holds that "The object of the idea constituting the human Mind is the Body, or a certain mode of Extension which actually exists, and nothing else." Spinoza elaborates in the scholium to lemma 7:

By this, then, we see how a composite Individual can be affected in many ways, and still preserve its nature. So far we have conceived an Individual which is composed only of bodies which are distinguished from one another only by motion and rest, speed and slowness, i.e., which is composed of the simplest bodies. But if we should now conceive of another, composed of a number of Individuals of a different nature, we shall find that it can be affected in a great many other ways, and still preserve its nature. For since each part of it is composed of a number of bodies, each part will therefore be able, without any change of its nature, to move now more slowly, now more quickly, and consequently communicate its motion more quickly or more slowly to the others. But if we should further conceive a third kind of Individual, composed of this second kind, we shall find that it can be affected in many other ways, without any change of its form. And if we proceed in this way to infinity, we shall easily conceive that the whole of nature is one Individual, whose parts, i.e., all bodies, vary in infinite ways, without any change of the whole Individual.[8]

Raymond Williams, adapting Gramsci's concept of hegemony, argues in his essay, "Base and Superstructure in Marxist Cultural Theory," that cultures can be described as dominant, emergent, and residual.[9] He is attempting to link certain forms of life to certain modes of economic production. Without taking these categories up in any detail, one can say that Williams' formulation represents a weak effort to work out sociologically the materialism that Spinoza catches in his pantheistic notion of the composite or whole individual. 
So not only are intellectuals aligned, as it were, with different cultures that are "contemporary" within the entire society; they are also affected differently and infinitely -- like all other composite individuals -- but "without any change of the whole Individual." It is, of course, such knowledge that we assume we can no longer have, caught, as we presumably are, within the varying historicities of subject-position and perspectives. To attempt to have is to attempt, in Aristotle's formulation, to achieve divine knowledge, it is to attempt what Spinoza lets us call "scientia intuitiva."[10]

Aristotle and Spinoza seem to feel that it is within human power to achieve such knowledge, which is a knowledge of the material whole. The problem that their assurance poses for contemporary intellectuals is caught up in the apparent apoliticism of it all. But how can that be? Negri, we recall, claims that, like Gramsci, Spinoza is powerfully formed by the tradition of revolutionary humanism, by the radical republican politics of Machiavelli, and so makes no distinction between politics and metaphysics. Surely no one would have it that Aristotle had no interest in politics! But their materialism, like Foucault's, could be called "quietist" by our contemporary intellectuals struggling, as we say, over matters of canon, race, gender, and ethnic diversity. Indeed, Second Part, Proposition 13 of The Ethics suggests that human agency makes no difference to the whole Individual. Yet this can be called quietist only if the will is mistaken for reality, for what Spinoza represents as the productive power of being, itself. And only if politics is so elided with the will -- of the individual or of the collective.

What is the whole Individual? Of course, it is perfection of essence in Spinoza. It is being as it is at a time. For Negri's Spinoza, being was the newly apparent market and colonial expansion. Disciplinary knowledge -that produced by the institutions organized within the absolute State -cannot provide access to this totality since it is its fragmented effect. Knowledge must be, in Negri's formulation of Spinoza's nominalism "set forward without delay toward the intuition of the concrete, of the ontologically determinate" (107). In opposition to will, Spinoza proposes the category of obedience; Negri, we can assume, highlights this notion (104) both because of Gramsci's attempts to think the nature of consent and because Martin Heidegger notion of Gelassenheit influenced certain elements in Negri's reading of Spinoza. According to this reading, Spinoza listens to the voice of being and reasons to a politics of consensus based upon obedience to a moderate State as the essential political form for all collective freedom.

This moderate State and the obedience it rests upon are the political forms of nominalism: so there are two ways to understand the whole Individual. First, the perfection of essence, that is, utopia; second, the state of being as it is at any time recognized by its most fully perfected state of production. 
The moderate State is an instance of this: it best fulfills the essence of collective freedom at one time.

In our age, nearly to quote Kierkegaard,[11] the whole Individual is still without question the market. But it is surely also a different and differentiating market. This is only to say that capital is revolutionary. Intellectuals must realize the force of Negri's perception: Spinoza's concept of obedience is logically expansive; that is, it grounds normality, obligation, but also liberation -- especially the "liberatory dignity of reason" (105), a claim resonant with Gramsci's comments against common sense. The consent that comes from obedience must be freely produced; yet the market we must now take as the highest and most developed form of capital, as the most "perfected" manifestation of "productive being," is almost beyond our reason, our understanding, and our consent.

Peter Schwartz, one-time political risk assessment officer for Royal Dutch Shell, the world's third largest corporation, and also a "strategic adviser to the London Stock Exchange" -- a person whose task was "to develop scenarios for the future of world finance markets" -- is an intellectual better placed than most literary academics to set knowledge forward toward the concrete. Let me quote him from a conversation with Stewart Brand published in the latter's book, The MIT Media Lab:

This century was shaped by the structure of industrialism. . . . A set of rules was enshrined toward the end of the nineteenth century about how life and the world was to be organized. It led to the cities, it led to the technology we have, it led to the economic structures that we have. . . . our technology has progressed so that increasingly the wealth-creation process has to do with information instead of with the material manipulations of manufacturing. That is, the value added in the transformation of stuff has to do with our capacity to understand and use information in various ways. ... how are the rules of that system going to be written? ... the two great systems that will dominate the new information-rich system are finance and electronic entertainment on a worldwide scale. . . In the case of finance, there are three things going on. The markets are becoming global, they interact, which drives globalization further, and they're huge. The newest numbers ... show that in 1986 international foreign exchange transactions reached $\$ 87$ trillion . . . . Twenty-three times the US. Gross National Product. . . . Until the early '70s, national governments were able to assure fixed rates of exchange by being the major players in the game .... It's not trade volumes, it's not physical activity that is driving the value of currencies any longer ... . Trade is only about ten percent of the $\$ 87$ trillion; it's trivial. Movement of money itself is the game. The shift is fundamental.[12] 
Of course a variety of positions have been elaborated to show the continuing relevance of Marxian theories to this new set of developments; indeed, we must all be Marxists, especially after Gramsci. Schwartz's way of discussing the new realities of global economics obviously need to be adjusted since it does not differentiate regional modes of production nor the specificities of race and especially gender in this new mode of production: who makes the commodity-like machines that enable this product-less production of value. Schwartz also writes the ideology of international capital under Thatcherism and Reaganism. Stuart Hall's The Hard Road to Renewal is useful in this area.[13] Yet even as an ideologically determined discourse of mainstream finance and economics, Schwartz's words name new modes of being in the world, new instrumentalities produced themselves from the activity of imagination and labor. That value is acutely alienated in such structures is clear; that a way of naming this alienation is necessary is also clear.

Schwartz is an "organic intellectual." He satisfies Gramsci's now classic definition: he gives his "social group" "homogeneity and an awareness of its own function not only in the economic but also in the social and political spheres." [14] What all intellectuals must come to grips with in Schwartz's talk is the fact of globality, and especially the fact of the relative decline in importance of the nation-state.[15] This is not to deny that States wage war, organize the interests of ruling elites, negotiate relations of geopolitics, etc. Nor is it to deny the continuing -- but I would say weakening -- efficacy of jurisprudential models of society, of constitutions, of regulative function at certain points in the economic and social systems. It is, however, to insist that the nation-state perspective, so common to the humanities and especially to Western literary studies for at least two centuries, is belated. Or to put the matter another way, it is to insist that only by assuring that intellectual devices correlative to the constitution of nation-states are still correlative to an economic order made up of global markets and global financial systems -- only such assurance can legitimate the discourses and practices of the so-called "intellectual groups." Indeed, it would also mean assuring the continuing correlation to new realities of the rhetorics of subjectivity which emerged within that nation-state time of constitutional movement towards absolutism. The issue, we might say, is contemporaneity.

At a conference held at the University of California at San Diego in the summer of 1991, Fredric Jameson made the argument, if I understood him correctly, that given the global nature of the market in Late Capitalism, even so-called "third-world intellectuals" aspire to a place in the global market, as evidenced by, for example, their speaking in English and wanting to be translated into English. The Sartrean intellectual is passé . Over and against this strong claim, I want to propose two types of counterexamples that also need to be taken seriously: first, the efforts of various writers in postcolonial cultures to use English to enter the market to resist the hegemony of a global market dominated by a few metropolitan classes and to create new solidarities across national lines -- this also poses a threat to the State and some of its theorists; second, efforts to produce local cultures, often regional 
in nature, based on communities that cross nation-state borders or operate in open defiance of state power -- one thinks especially of Ngugi in this case. [16]

Rob Wilson of the University of Hawaii and Arif Dirlik of Duke University are now at work assembling a special issue of boundary 2 on the literature and culture of the countries on the margins of what US planners call "the Pacific Rim."[17] To put the matter simply and too reductively they are attempting to give historical substance and specificity to the claims for syncreticity made about postcolonial writing by the authors of such books as The Empire Strikes Back.[18] In particular, they are attending to the ways "English" comes to be used as a mode for producing resistance to the former colonizer as well as to the nationalizing impulses of local nationalist regimes. The novels and stories of Albert Wendt might be offered as important examples. [19]

Spinoza, as Negri tells the tale, catches the market as it seems to make possible collective freedom, as it both reveals being as productive and the human role in that production as collective freedom -- what we might call the perfection of the human in being. We do not easily, thanks, in part, to the work of Gayatri Spivak, imagine notions of perfection or innocence in the formerly "exotic" writings of postcolonial peoples. We know enough to look for the traces of the dominant market and its systems of value-production even in the works of regional autonomy or resistance: gender problems come to mind immediately. Yet, in Spinoza, perfection has a less teleological sense as well; it means not only the fullness of essence at the end of time as it were; it means rather a sort of eternal or infinite project wherein perfection exists as the highest development possible at a given stage in the maturation of being.

We need to be able to judge, to recognize the contemporaneity of cultural production, if you will, with the highest forms of being's production, represented in this case by the extreme globality of systems in relation to local resistances and autonomies. This means a recognition not only of resistance to the global market as a new form of hegemony and empire; not only an effort to join that market for "subversive" purposes; it means something like a recognition of what used to be called "sin," that is, the irrationality of commitment to what is not most perfected, namely, a commitment to what does not further the collective project of collective freedom. It means, for example, recognizing that the global market's assaults on the autonomy, power, and legitimacy of state relations, of state relations as a dialectical evolution of civil society and its so-called constituent units, does mark an evolution of being beyond the forms of the nation-state. It means recognizing that this also makes demands on contemporary intellectuals to set their knowledge towards the being of the present. 
Where should we lend the support of our efforts? The most mature state of being is still imperfect and, Spinoza shows that perfection is liberation, intuitive knowledge. Intellectuals' contribution to perfection involves applying the constitutive power to a disclosure of the structures of being and judging the maturity of being, judging the relative powers of sin and perfection would mean judging the truth: that is, judging with certainty the degree of correlation between actions that lead us nearer to the model we propose for human being and those that lead us away (Negri, 157). Perfection, then, is not in the future; it can be made contemporary by liberation of what each thing might be insofar as it both is itself and, as Spinoza says, insofar as it produces an effect -- and effects can be understood in terms of their value of moving towards the liberation that alone will approximate what Negri calls the "model that we propose for human nature" (157).

What then might we say of such a thing as Ngugi's position in Decolonising the Mind?[20] Contrary to Jameson's claims about the universal rush to English as a trace of the global market's absolute preemption of human being, Ngugi's claims for /pp. 17-18/ necessary writing in the regional languages of what we might call "sub-national" groupings have a lucid commitment to the struggle for perfection:

This is what this book on the politics of language in African literature has really been about: national, democratic and human liberation. The call for the rediscovery and the resumption of our language is a call for a regenerative reconnection with the millions of revolutionary tongues in Africa and the world over demanding liberation. It is a call for the rediscovery of the real language of humankind: the language of struggle. It is the universal language underlying all speech and words of our history. Struggle. Struggle makes history. Struggle makes us. In struggle is our history, our language and our being. (p.108)

What does this struggle consist in? Recently, for Ngugi, struggle consists in the effort to translate critical essays written in English into "essais " written in Gikuyu language. The process marks an important incommensurability, a non-contemporaneity between languages and peoples in the world made up, in large part, by the global market. The struggle Ngugi speaks of is both the physical struggle of resistance that sends writers to jail for the actions taken against the nationalist State and the struggle to turn language toward reality, toward the structure of being as it now is, to let language liberate human nature as it is where it is. The location of this human nature is the existence of a population that has no language for the discussion of what Spinoza calls "mature being," that is, current forms of production -- except, of course, for the language of the colonizers and metropolitans, even as these are adapted and syncretized by postcolonial authors. 
Perhaps Gikuyu language as Ngugi speaks of it could too easily become the object of romance for Western critics, except that what Ngugi proposes is immensely difficult.[21] The difficulty, however, is not itself the issue; nor is the ease with which metropolitans might "heroicize" the attempt; nor is the pathos of the struggle, the romance of desire and failure it might contain. More important is the intellectual obligation to make language speak perfection, to liberate the essence, describe the structures of being as it has been and is produced through the constitutive efforts of the human. Acquiring godlike knowledge is not mere consumption; it is production of what is constitutive; it is valorizing of what is true; truth is the adequation of a constellation of ideas to constellations of reality. And so it is not utopian. It is the work of the here and now for as diverse as are the various moments and positions of the present, there is an integral wholeness to it all which needs to be named, or which can be seen through a naming of its "parts."

Without Foucault's strong work on power and its constitutive force, Negri would not have written his book on Spinoza. Without Gramsci and his insistence on collectivity, on overcoming common sense, on the value of philosophy, and on the need to observe the leading forms of production, Negri would not have written on Spinoza as he did. All this means merely that the contemporary intellectual is a function of others whose efforts give effect to his or her essence. Mere historicity does not determine the relations of contemporaneity between Foucault, Spinoza, Wendt, and the others. Nor is it merely asserted by a yet more belated interpreter. Such a claim would be weak perspectivism. Rather the continual effort to liberate things as they are, to liberate human being, to let human being become its formative liberation -- all these constitute an alignment among those who are contemporary.

To what end? The Heidegger and Foucault who enable Negri to listen to Spinoza name the "model" implicitly at least proposed for human nature: Heidegger calls it generosity; Foucault speaks of the reversibility of relations within power as freedom; Negri's Spinoza speaks of "obedience" and "consent" -- but not as contract theory -- while Gramsci speaks endlessly of dirigente as a form of intellectual leadership which will not be totalitarian nor presumptuous, that will rather name the being newly produced, and try to liberate the collective praxis to constitute a new model assumed to be best for human nature.[22]

The enemy, the sin, as it were for this model, as for Gramsci's, goes by the name of fascism or the absolute state. The imperfection is the use of aesthetics, criticism, and power to produce subjectivities and institutions that, if you will, vote for David Duke or Jean-Marie LePen. In other words, sin is that kind of power which produces insecurity, hatred, murder, internecine warfare, and so on -- all to the end of maintaining itself. It is, if you will, what names the struggles of Serb and Croat mere nationalist 
hysteria; worse, it is what disposes Serb and Croat and others to the mass illusion of misdirected conflict. We can, of course, call this "the market." We can call it the desire for consumer goods, for "individual freedom." We can call it the result of nationalist resentments "penned up" by Communism. But we also need to ask if we cannot do better in naming so that the fact and the potential for humans to constitute reality in and alongside production cannot become clearer. We need to ask if first, in the name of our own best understanding of desirable models, if we have named the current state of being and if, having done so, we have tried to destroy the sinful forms of power where we find them. If we have not done at least most of that, we cannot be contemporary with either those who have tried before and who might still help us now nor can we be contemporary with those whom we might now help by giving some effect to our efforts to be "contemporary."

\section{Paul A. Bové}

\section{Department of English}

\section{University of Pittsburgh}

\section{e-mail bove@vms.cis.pitt.edu}

\section{Surface Page d'Acceuil/Home Page}

[1]See, for example, Alexander Nehamas, Nietzsche: Life as Literature (Cambridge: Harvard University Press, 1985), esp. pp. 35 - 41.

[2] Much of this line of narrative can be understood as an easy adaptation of Gramsci's assertion that all humans are intellectual.

[3]See as well Michel Foucault's repetitive elaboration on this problem of "contemporaneity," "What is Enlightenment," in The Foucault Reader, ed. Raul Rabinow (NewYork: Pantheon Books, 1984), pp. 32 - 50.

[4]Antonio Negri, The Savage Anomaly: The Power of Spinoza's Metaphysics and Politics, trans. Michael Hardt (Minneapolis: University of Minnesota Press, 1991), pp. 17 - - 20. Originally published as L'anomalia selvaggia. Saggio su potere e potenza in Baruch Spinoza, 1981. Hereafter cited in my text by page number.

[5]For a discussion of some of these matters see Paul A. Bové, Intellectuals in Power (New York: Columbia University Press, 1986). 
[6]Wlad Godzich has recently begun to argue persuasively and provacatively that it is the death of culture that affords the newly fashionable "cultural studies" its cachet. His assertion of the death of culture came most recently in a hitherto unpublished manuscript talk delivered in Amherst under the title, "Prolegomenon to New Political Discourse." (see also his contribution to this volume -- Ed.)

[7]Negri, p. 66.

[8]Bento de Spinoza, "The Ethics," The Collected Works of Spinoza, ed. and trans. by Edwin Curley (Princeton: Princeton University Press, 1985), p. 461.

[9]Problems in Materialism and Culture (London: Verso, 1980), pp. 31 - 49.

[10]See Curley, p. 478, Second Part of "The Ethics," proposition XL, scholium 2: "In addition to these two kinds of knowledge, there is . . . another, third kind, which we shall call intuitive knowledge."

[11]Søren Kierkegaard, "The Present Age," Two Ages: The Age of Revolution and the Present Age, trans. Howard V. Hong and Edna H. Hong (Princeton: Princeton University Press, 1978), pp.68ff. Originally published as a review in 1845 .

[12]Stewart Brand, The MIT Media Lab: Implementing the Future at MIT (New York: Viking Books, 1987), pp. 230 - 32.

[13]The Hard Road to Renewal (London: Verso, 1988).

[14]Antonio Gramsci, Selections from the Prison Notebooks, eds. and trans. Quintin Hoare and Geoffrey Nowell Smith (New York: International Publishers, 1971), p. 5.

[15] See once again the continuing recent work of Wlad Godzich in this area, much of which is only now beginning to be published.

[16]Basil Davidson's discussion of borders and smuggling in his book, The Black Man's Burden: Africa and the Curse of the Nation-State, makes this point clear and concrete in a specific postcolonial setting. (New York: Times Books, 1992), pp. 99ff.

[17]Forthcoming, Spring, 1994 (Vol 21, no. 1).

[18]Bill Ashcroft, Gareth Griffiths, and Helen Tiffin, The Empire Writes Back: Theory and Practice in Post-Colonial Literatures (New York: Routledge, 1989).

[19]See, for example, sons for the return home (Auckland: Penguin Books, 1987); first published by Longman, 1973.

[20]Ngugi wa Thiong'o, Decolonising the Mind: The Politics of Language in African Literature (London: James Currey, 1986). 
[21]Indeed, an important objection to Ngugi's efforts would be that he hopes to extend the western and statist notion of literature to Gikuyu language and language speakers. This is an important point with immense consequence for thinking about postcolonial writing. Others have dealt with it at length and the topic is too complex to take up now. Edward W. Said's forthcoming summa, Culture and Imperialism, explores the topic in a more complex fashion than anything else I know. (New York: Knopf, 1993); a Borzoi Book.

[22]Said, in a forthcoming interview in boundary 2 (vol 20, no. 1) discusses a similar theme. Offered the chance to call his attitude in Culture and Imperialism, "generous," he announces that he prefers "integrative." Said makes his case precisely in the context of arguing against the dominance of "identity" and "difference" in modern criticism and politics while making the case for a new look at "human nature." 